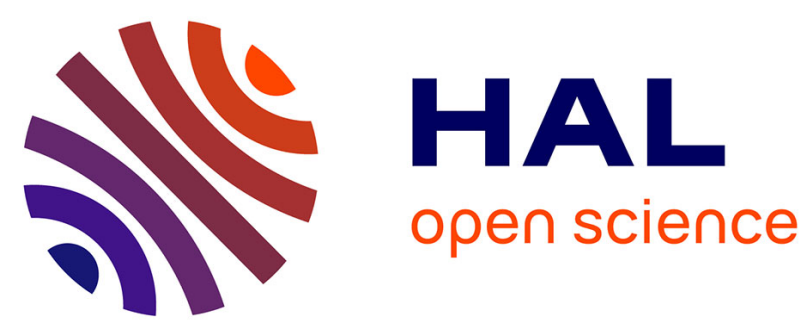

\title{
Relation between subduction megathrust earthquakes, trench sediment thickness and upper plate strain
}

\author{
Arnauld Heuret, C. P. Conrad, F. Funiciello, Serge Lallemand, L. Sandri
}

\section{To cite this version:}

Arnauld Heuret, C. P. Conrad, F. Funiciello, Serge Lallemand, L. Sandri. Relation between subduction megathrust earthquakes, trench sediment thickness and upper plate strain. Geophysical Research Letters, 2012, 39, pp.L05304. 10.1029/2011GL050712 . hal-00745636

\section{HAL Id: hal-00745636 \\ https://hal.science/hal-00745636}

Submitted on 16 Dec 2015

HAL is a multi-disciplinary open access archive for the deposit and dissemination of scientific research documents, whether they are published or not. The documents may come from teaching and research institutions in France or abroad, or from public or private research centers.
L'archive ouverte pluridisciplinaire HAL, est destinée au dépôt et à la diffusion de documents scientifiques de niveau recherche, publiés ou non, émanant des établissements d'enseignement et de recherche français ou étrangers, des laboratoires publics ou privés. 


\title{
Relation between subduction megathrust earthquakes, trench sediment thickness and upper plate strain
}

\author{
A. Heuret, ${ }^{1,2}$ C. P. Conrad, ${ }^{3}$ F. Funiciello, ${ }^{1}$ S. Lallemand, ${ }^{2}$ and L. Sandri ${ }^{4}$ \\ Received 21 December 2011; revised 3 February 2012; accepted 7 February 2012; published 3 March 2012.
}

[1] Giant earthquake (moment magnitude $M_{w} \geq 8.5$ ) forecasts for subduction zones have been empirically related to both tectonic stresses and geometrical irregularities along the subduction interface. Both of these controls have been suggested as able to tune the ability of rupture to propagate laterally and, in turn, exert an important control on giant earthquake generation. Here we test these hypotheses, and their combined influence, by compiling a dataset of trench fill thickness (a proxy for smoothing of subducting plate relief by sediment input into the subduction channel) and upper plate strain (a proxy for the tectonic stresses applied to the subduction interface) for 44 segments of the global subduction network. We statistically compare relationships between upper plate strain, trench sediment thickness and maximal earthquake magnitude. We find that the combination of both large trench fill $(\geq 1 \mathrm{~km})$ and neutral upper plate strain explains spatial patterns of giant earthquake occurrence to a statistically significant degree. In fact, the concert of these two factors is more highly correlated with giant earthquake occurrence than either factor on its own. Less frequent giant earthquakes of lower magnitude are also possible at subduction zones with thinner trench fill and compressive upper plate strain. Extensional upper plate strain and trench fill $<0.5 \mathrm{~km}$ appear to be unfavorable conditions, as giant earthquakes have not been observed in these geodynamical environments during the last 111 years. Citation: Heuret, A., C. P. Conrad, F. Funiciello, S. Lallemand, and L. Sandri (2012), Relation between subduction megathrust earthquakes, trench sediment thickness and upper plate strain, Geophys. Res. Lett., 39, L05304, doi:10.1029/2011GL050712.

\section{Introduction}

[2] Giant earthquakes (GEQ; moment magnitude $M_{w} \geq$ 8.5) usually occur on plate-bounding faults between the subducting and overriding plates of converging margins. Despite an obvious relevance to seismic hazard, it remains unclear which, if not all, of Earth's subduction zones can produce such devastating events [e.g., Ruff and Kanamori, 1980; Jarrard, 1986; Ruff, 1989; Pacheco et al., 1993; Conrad et al., 2004; McCaffrey, 2008; Heuret et al., 2011; Normile, 2011]. Recent analysis of the Gutenberg-Richter law applied to worldwide subduction thrust faults, however,

\footnotetext{
${ }^{1}$ Dipartimento Scienze Geologiche, Università “Roma TRE,” Rome, Italy.

${ }^{2}$ Géosciences Montpellier, CNRS, Université Montpellier 2, Montpellier, France.

${ }^{3}$ Department of Geology and Geophysics, University of Hawaii at Manoa, Honolulu, Hawaii, USA.

${ }^{4}$ Istituto Nazionale di Geofisica e Vulcanologia, Bologna, Italy.

Copyright 2012 by the American Geophysical Union. 0094-8276/12/2011GL050712
}

shows that energy release by interplate seismicity differs among convergent margins, and some appear more prone to GEQ production than others [Marzocchi et al., 2011]. One of the most striking and consistent characteristics of GEQs, when compared to smaller interplate events, is the large trench-parallel length over which they rupture $(250 \mathrm{~km}$ to $>1000$ km [e.g., Kostoglodov, 1988; McCaffrey, 2008]). Enhancing a rupture's ability to propagate in the trenchparallel direction, breaking an increasingly larger number of thrust fault "segments", thus amplifies the magnitude of a seismic event. This process was recently illustrated by the Tohoku earthquake [e.g., Meng et al., 2011].

[3] The spacing and nature of geometrical irregularities along the interplate contact, controlled primarily by subducting sediments and subducting plate relief, seems to regulate the ability of the rupture to propagate laterally. Several authors have indeed demonstrated that subducting seamounts or ridges may either act as seismic asperities triggering earthquakes (e.g., off Costa-Rica [Bilek et al., 2003]) or as seismic barriers (e.g., along the Nankai margin [Kodaira, 2000; Wang and Bilek, 2011]). Spring-block, gelatin-sand paper analogue models of subduction thrust faults have confirmed the important role of interface geometrical irregularities for controlling both static and non-static friction, the latter showing negative values (i.e., seismic behavior) only for specific roughness amplitudes and spacings [Corbi et al., 2011]. On a subducting plate interface, relief may be diminished where abundant sediments are subducting. If lower plate relief is smaller than subduction channel thickness, trench sediment may form a homogenous layer between the upper and lower plates that smoothes subducted seafloor and strength-coupling asperities. As first proposed by Ruff [1989], such a homogeneous interface favors long trench-parallel propagation of the rupture and large earthquakes magnitudes.

[4] Because subduction channel sediments are difficult to observe seismically, their influence on GEQs must be tested indirectly by assuming that trench sediments are representative of those in the subduction channel at seismogenic depths (Figure 1a). This basic assumption, however, must still be substantiated in the light of the various tectonic processes that the sediment layer encounters during its travel at depth. In fact, trench fill thickness may differ substantially from values present in the seismogenic zone, either because trench fill may accrete frontally into the wedge (e.g., the southern Ryukyu Islands [Schnürle et al., 1998]) or because thin trench sediments may be associated with a thick subduction channel when tectonic erosion occurs [von Huene and Lallemand, 1990; Lallemand et al., 1994]. In the latter case, the additional material eroded from the upper plate into the subduction channel may be 5 to 10 times larger than the input sediments [e.g., Lallemand, 1995; Clift and Vannucchi, 2004], i.e., the thinnest trench sediments may be associated with the thickest 


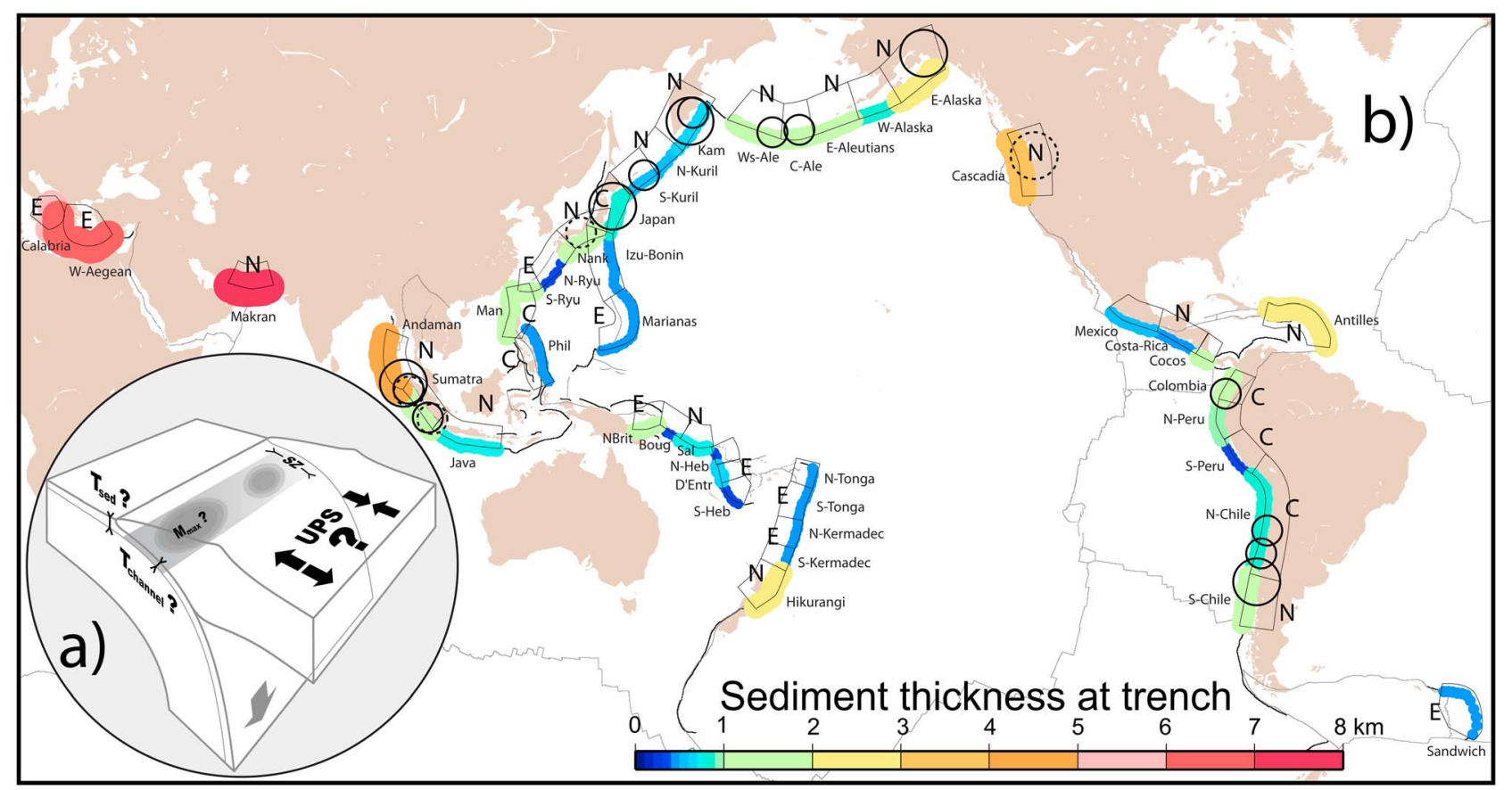

Figure 1. (a) Possible relationships between subduction megathrust earthquakes, trench sediment thickness and upper plate strain. Abbreviations: Upper plate strain (UPS), thickness of sediments in the trench $\left(T_{\text {sed }}\right)$, thickness of the subduction channel $\left(T_{\text {channel }}\right)$, maximum earthquake magnitude $\left(M_{\max }\right)$, and seismogenic zone $(\mathrm{SZ})$. (b) Map of the 44 trench segments defined by Heuret et al. [2011], showing the variability of $T_{\text {sed }}$ (colors) and UPS ( $\mathrm{E}=$ Extensional, $\mathrm{N}=$ Neutral, $\mathrm{C}=\mathrm{Com}$ pressive). Black circles show the location of $M_{w} \geq 8.5$ subduction interface earthquakes (area scales with magnitude). Preinstrumental events are represented by dashed circles.

subduction channels. Furthermore, subduction history may introduce additional bias. For instance, the Southern Chile margin was erosional until glaciation introduced large volumes of new trench sediments 3 Ma ago [Lamb and Davis, 2003]. Given convergence rates, sediments at seismogenic zone depths may thus be thinner than indicated by current large trench fill. Under such conditions, it is not surprising that the few high-resolution images of subduction interfaces at the $\sim 10 \mathrm{~km}$ upper limit of seismogenic zone depths (e.g., off Japan [von Huene et al., 1994], Colombia-Ecuador [Agudelo et al., 2009] or Andaman-Sumatra [Singh et al., 2008]) have imaged subduction channels with large thickness variabilities. Despite these potential biases, Scholl et al. [2011] demonstrated that trench sectors with axial deposits thicker than $1.0 \mathrm{~km}$ are associated with the occurrence of an unusually high number of GEQ $\left(52 \%\right.$ of $M_{w}>8.0,57 \%$ of $M_{w}>8.3$, and $67 \%$ of $M_{w}>8.5$ ), suggesting that trench sediments provide useful information about subduction channel smoothing. Alternative interpretations for sediment influence on GEQ genesis (e.g., the role of fluids, the nature of subducted material, the role of metamorphism) cannot be ruled out.

[5] Tectonic stresses applied on the subduction interface, which may be inferred from deformation in the back-arc [Lallemand et al., 2008], may also affect the earthquake magnitude potential. Uyeda and Kanamori [1979] suggested that compressive back-arcs promote larger earthquake magnitudes because they are associated with greater coupling across the subduction interface, and in particular stronger stress accumulations along larger asperities [Ruff and Kanamori, 1980]. However, Heuret et al. [2011] show that instrumentally-recorded GEQs are instead most often associated with neutral back-arcs, only secondarily with upper plate compression, and never with extensional domains. The relative lack of GEQs in compressive zones may be attributed to the large critical stresses needed to rupture individual asperities under strong compression. Thus, even if rupture of an initial asperity releases relatively large seismic moment, the propagation of this rupture to neighboring asperities may be hindered by compressive tectonics, thus diminishing the possibility for GEQ generation [Heuret et al., 2011]. The opposite scenario occurs with extensional UPS, where asperities are expected to be smaller and can be ruptured by lower critical stresses. However, the smaller seismic moment released by initial rupture may limit the possibility for propagating rupture of multiple asperities in a single mega-event. Thus, the statistical association of GEQs with neutral subduction zones may result from a favorable interplay between a large initial seismic moment release at individual asperities and a low critical stress required for lateral rupture propagation [Corbi et al., 2011].

[6] Thus, it is not clear whether subduction channel sediments or tectonic stresses on the plate interface regulate earthquake potential size (Figure 1a). In the present study, we explore the plate interface conditions for GEQ genesis by statistically analyzing, for worldwide subduction zones, the relations between upper plate strain (UPS), sediment thickness at the trench $\left(T_{\text {sed }}\right)$, and the maximum yet-observed earthquake magnitude $\left(M_{\max }\right)$.

\section{Dataset}

[7] We have described $M_{\max }, T_{\text {sed }}$ and UPS for a set of 44 trench sections identified as exhibiting homogeneous 


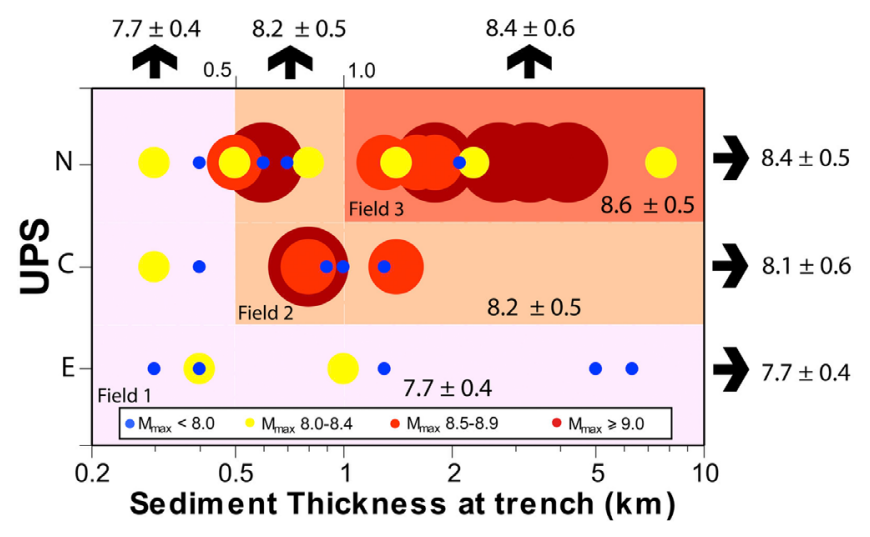

Figure 2. Relation between the maximum earthquake magnitude $M_{\max }$ at each of the 44 trench segments (Figure 1b), and the trench sediment $\left(T_{\text {sed }}\right)$ and upper plate strain (UPS) characteristics of those segments. $M_{\max }$ classes are represented by colored dots. A logarithmic scale has been used for the $T_{\text {sed }}$ axis. Symbols for UPS classes $(\mathrm{E}, \mathrm{N}, \mathrm{C}$ ) are as in Figure $1 \mathrm{~b}$. The $M_{\max }$ mean values and standard deviations obtained by considering the different categories of UPS are given along the right side of the figure. Those related to increasing $T_{\text {sed }}$ values $\left(T_{\text {sed }}<0.5 \mathrm{~km}, 0.5 \mathrm{~km} \leq T_{\text {sed }}<\right.$ $1.0 \mathrm{~km}$, and $T_{\text {sed }} \geq 1.0 \mathrm{~km}$ ) are given along the upper side of the figure. $M_{\max }$ mean values are also specified for combinations of $T_{\text {sed }}$ and $U P S$ conditions by defining 3 different $\left[T_{\text {sed }} ; U P S\right]$ fields of increasing earthquake magnitude potential $\left(M_{\max }\right.$ mean value increases toward the upper right of the figure). Field 1 (pink): $\left[T_{\text {sed }}<0.5 \mathrm{~km}\right]$ and/or $[U P S=\mathrm{E}]$; no GEQ Field 2 (orange): $\left[T_{\text {sed }} \geq 0.5 \mathrm{~km} ; U P S=\mathrm{C}\right]$ or $[0.5 \leq$ $\left.T_{\text {sed }}<1.0 \mathrm{~km} ; U P S=\mathrm{N}\right]$; larger earthquake magnitudes, including some GEQ Field 3 (red): $\left[T_{\text {sed }} \geq 1 \mathrm{~km}\right.$; UPS = $\mathrm{N}$; most of the known GEQs.

along-strike megathrust seismogenic zone behavior by Heuret et al. [2011] (Figure 1b). Narrow subduction zones (e.g., Yap, Palau, Puysegur), trench sections with too low seismic activity (e.g., Patagonia, Venezuela, Panama, Muertos) and those without available $T_{\text {sed }}$ data (e.g., Wetar, Flores) were removed from the original set of 62 trench sections. The 44 selected trench sections were systematically sampled every $1^{\circ}$ of trench, resulting in a total of 399 sampled points.

[8] Subduction parameter datasets have been previously published for $M_{\max }$ and UPS data. We improved the 1900$2007 M_{\max }$ dataset of Heuret et al. [2011] by extending the time period analysis to 2011 and by considering pre-instrumental events from the Nankai, Cascadia, Sumatra [Satake and Atwater, 2007], and Antilles [USGS Historic World Earthquakes list] trench sections. For UPS, we have used a simplified version of the classification described by Heuret and Lallemand [2005], based on earthquake focal mechanisms occurring less than $40 \mathrm{~km}$ beneath the surface of the upper plate, far from the subduction interface: extensional (E; extension, primarily characterized by the occurrence of active back-arc spreading or rifting), compressive (C; compression, primarily characterized by significant shortening on lithospheric back-arc thrusts) and neutral ( $\mathrm{N}$; strike-slip, no significant deformation, low extension or compression).

[9] To estimate trench sediment thicknesses, we developed an original dataset by compiling 160 independent local reflection seismic lines (Table S1 in the auxiliary material), which comprise $\sim 40 \%$ of the total length of subduction zones (Figure S1 in the auxiliary material). ${ }^{1}$ This dataset not only provides $T_{\text {sed }}$, the mean trench sediment thickness for each of the 44 trench sections, but also some constraints on the lateral variability observed along each trench section (Table S2 in the auxiliary material). This database, as well as associated references and discussions, are detailed in the auxiliary material.

\section{Analysis and Results}

[10] We relate both $T_{\text {sed }}$ and UPS conditions at each subduction zone to observed $M_{\max }$ (Figure 2). In the present study, we chose to distinguish trench sections with $T_{\text {sed }}<$ $0.5 \mathrm{~km}$ from those with $0.5 \leq T_{\text {sed }}<1.0 \mathrm{~km}$ and $T_{\text {sed }} \geq$ $1.0 \mathrm{~km}$. The $T_{\text {sed }}=0.5 \mathrm{~km}$ and $T_{\text {sed }}=1.0 \mathrm{~km}$ threshold values have been arbitrarily fixed because $T_{\text {sed }}=0.5 \mathrm{~km}$ is the mean value for the thickness of pelagic sediments (i.e., trenches with $T_{\text {sed }} \geq 0.5 \mathrm{~km}$ are those that are not only filled by pelagic sediments, but also by detritic sediments from the overriding plate) and because margins where $T_{\text {sed }} \geq 1.0 \mathrm{~km}$ commonly develop accretionary wedges. We verified the observations that mean values of $M_{\max }$ progressively increase as sediment fill increases (see auxiliary material). However, although $T_{\text {sed }} \geq 1.0 \mathrm{~km}$ is associated, on average, with the largest earthquakes (mean $M_{\max }=8.4$ ), it is not a necessary condition for GEQ genesis. Indeed, some of the thickest subducted sediment layers, such as those of W-Aegean and Calabria $\left(T_{\text {sed }} \geq 5 \mathrm{~km} ; M_{\max }<8.0\right)$, have never been associated with GEQs. However, some trenches with abundant sedimentation converge slowly [e.g., Clift and Vannucchi, 2004], which increases GEQ recurrence time and thus diminishes the chances of GEQ observation in historical times, or are confined in extent, which limits possible rupture length and thus GEQ occurrence. Alternatively, the Kamchatka, S-Kuriles, Japan and N-Chile subduction zones produced great earthquakes $\left(M_{\max }=8.6-9.1\right)$ with thinner sediments $\left(T_{\text {sed }}=0.5-0.8 \mathrm{~km}\right)$. Thus, it seems that $0.5 \leq T_{\text {sed }}<1.0 \mathrm{~km}$ is sufficient for GEQs to occur.

[11] We have plotted UPS classes by considering their theoretically-increasing ability to promote large trench-parallel earthquake rupture (i.e., $\mathrm{E}<\mathrm{C}<\mathrm{N}$ [after Heuret et al., 2011]). Using this classification, we verified that mean values of $M_{\max }$ progressively increase from extensional to compressional to neutral UPS (see auxiliary material). No GEQs have been observed in association with extensional UPS (the 2004, $M_{w}=9.0$ Sumatra event was not an exception; only the northernmost part of the Andaman margin is extensive, whereas the earthquake nucleated in Northern Sumatra, in an area characterized by a neutral UPS). The largest earthquakes are, on average, associated with neutral $U P S$ (mean $M_{\max }=8.4$ ), but some GEQs have also been observed in association with compressive UPS (Japan, $\mathrm{N}$-Chile and Colombia).

[12] In the $\left[T_{\text {sed }} ; U P S\right]$ domain of Figure 2, we thus define 3 different fields defined by specific combinations of $T_{\text {sed }}$ and UPS associated with increasing earthquake magnitude potential. GEQs have not been observed at trench sections where UPS is extensional or where $T_{\text {sed }}<0.5 \mathrm{~km}$ (Field 1).

${ }^{1}$ Auxiliary materials are available in the HTML. doi:10.1029/ 2011 GL050712. 
a)

\begin{tabular}{|l|c|c|c|c|}
\hline$T_{\text {sed }}^{M_{\max } \text { class }}$ & $M_{\max }<8.0$ & $M_{\max } 8.0-8.4$ & $M_{\max } 8.5-8.9$ & $M_{\max } \geqslant 9.0$ \\
\hline \multirow{2}{*}{$<0.5 \mathrm{~km}$} & $26.0 \%$ & $50.5 \%$ & $3.5 \%$ & $100 \%$ \\
& $87.1 \%$ & $71.7 \%$ & $3.5 \%$ & $5.7 \%$ \\
\hline \multirow{2}{*}{$0.5-0.9 \mathrm{~km}$} & $63.9 \%$ & $51.4 \%$ & $48.8 \%$ & $39.8 \%$ \\
& $58.2 \%$ & $73.2 \%$ & $81.1 \%$ & $87.3 \%$ \\
\hline \multirow{2}{*}{$\geqslant 1.0 \mathrm{~km}$} & $84.2 \%$ & $77.5 \%$ & $9.2 \%$ & $17.1 \%$ \\
& $30.4 \%$ & $44.2 \%$ & $98.1 \%$ & $96.1 \%$ \\
\hline
\end{tabular}

b)

\begin{tabular}{|c|c|c|c|c|}
\hline UPS $^{M_{\max } \text { class }^{-}}$ & $M_{\max }<8.0$ & $M_{\max } 8.0-8.4$ & $M_{\max } 8.5-8.9$ & $M_{\max } \geqslant 9.0$ \\
\hline \multirow{2}{*}{$E$} & $1.1 \%$ & $57.4 \%$ & $100 \%$ & $100 \%$ \\
\hline \multirow{2}{*}{$\mathrm{C}$} & $47.9 \%$ & $90.1 \%$ & $5.4 \%$ & $8.2 \%$ \\
\hline \multirow{2}{*}{$\mathrm{N}$} & $80.2 \%$ & $28.5 \%$ & $37.4 \%$ & $72.0 \%$ \\
& $\mathbf{0 . 7} \%$ & $36.6 \%$ & $20.1 \%$ & $9.4 \%$ \\
\hline
\end{tabular}

\begin{tabular}{|c|c|c|c|c|}
\hline Field $M_{\text {max }}^{\text {class }}$ & $M_{\max }<8.0$ & $M_{\max } 8.0-8.4$ & $M_{\max } 8.5-8.9$ & $M_{\max } \geqslant 9.0$ \\
\hline 1 & $\begin{array}{l}38.8 \% \\
77.8 \%\end{array}$ & $\begin{array}{l}80.2 \% \\
40.0 \%\end{array}$ & $0.2 \%$ & $0.5 \%$ \\
\hline 2 & $\begin{array}{l}23.4 \% \\
89.8 \%\end{array}$ & $\begin{array}{l}52.5 \% \\
73.1 \%\end{array}$ & $\begin{array}{l}18.1 \% \\
95.7 \%\end{array}$ & $\begin{array}{l}39.7 \% \\
87.0 \%\end{array}$ \\
\hline 3 & $\begin{array}{l}98.8 \% \\
7.2 \%\end{array}$ & $\begin{array}{l}45.0 \% \\
79.5 \%\end{array}$ & $3.0 \%$ & $1.4 \%$ \\
\hline \multirow{2}{*}{\multicolumn{2}{|c|}{ 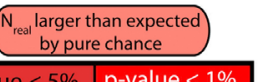 }} & \multicolumn{2}{|c|}{\begin{tabular}{|l|l}
$\mathrm{N}_{\text {real }}$ lower than expected \\
by pure chance
\end{tabular}} & \multirow{2}{*}{$\begin{array}{c}\text { Pure chance can } \\
\text { explain } N_{\text {real }} \text { at } \geqslant 5 \% \\
\text { significance level }\end{array}$} \\
\hline & & & & \\
\hline
\end{tabular}

Figure 3. Results of the Monte Carlo simulations, as discussed in the auxiliary material. (a) p-values of two null hypothesis tests, performed for each of the $T_{\text {sed }}$ conditions and $M_{\max }$ classes described in Figure 2 (based on the distributions in Figure $\mathrm{S} 3$ in the auxiliary material): $\mathrm{H}_{0-1}: N_{\text {synth }} \geq$ $N_{\text {real }}$ and $\mathrm{H}_{0-2}: N_{\text {synth }} \leq N_{\text {real }}$. The cases in which a significant $\mathrm{p}$-value is obtained are marked in red or blue if the test rejects respectively the $\mathrm{H}_{0-1}$ or the $\mathrm{H}_{0-2}$ null hypothesis at the $5 \%$ significance level. The red/blue cells show the sets of $T_{\text {sed }}$ conditions (vertical axis) and $M_{\max }$ classes (horizontal axis) where the number of observed subduction zones is significantly higher/lower than expected by random chance (i.e., p-value $<5 \%$ ). In the cells where $N_{\text {real }}$ can be explained by pure chance (both p-values are $>5 \%$ ) the background is grey. p-values associated with the $\mathrm{H}_{0-1}$ and $\mathrm{H}_{0-2}$ null hypotheses (these cases can be explained by random chance) are given at the top and bottom of the cell, respectively. (b) Same as Figure 3a, but for categories of UPS type (based on the distributions in Figure S4 in the auxiliary material). (c) Same as Figure $3 \mathrm{a}$, but for conditions on $T_{\text {sed }}$ and UPS jointly, as defined by the three $\left[T_{\text {sed }} ; U P S\right]$ fields in Figure 2 (based on the distributions in Figure S5 in the auxiliary material).

These subduction zones produce the lowest $M_{\max }$ mean values. Conversely, the conditions that are most associated with the largest GEQs are neutral back-arcs and $T_{\text {sed }} \geq$ $1.0 \mathrm{~km}$ (Field 3). In between, i.e., trench sections where compressive UPS is associated with $T_{\text {sed }} \geq 0.5 \mathrm{~km}$, or where a neutral UPS is associated with $0.5 \leq T_{\text {sed }}<1.0 \mathrm{~km}$ (Field 2), GEQs are possible, although with smaller mean $M_{\max }$ than in Field 3.

[13] To quantify the robustness of these observed correlations, we performed a set of statistical Monte Carlo simulations to determine the probability that the above-described patterns may arise by random chance. Here, we present the results of 10,000 simulated datasets, each consisting of 44 zones with randomly sampled $T_{\text {sed }}$ (from the empirical cumulative distribution, Figure S2 in the auxiliary material), and randomly permuted (from the set of observed values) UPS nature and $M_{\max }$ values. Thus, our synthetic datasets have the same distribution of the observed $M_{\max }$ attached to a randomized pair $\left[T_{\text {sed }} ; U P S\right]$. We compare these synthetic datasets with real data, distinguishing among 4 different classes of maximum observed magnitude (as in Figure 2: $M_{\max }<8.0 ; 8.0 \leq M_{\max }<8.5 ; 8.5 \leq M_{\max }<9.0 ; M_{\max } \geq 9.0$ ).

[14] First, we check whether $T_{\text {sed }}$ or UPS by themselves can explain the $M_{\max }$ distribution observed in Figure 2. For $T_{\text {sed }}$, we compare the real number $\left(N_{\text {real }}\right)$ of subduction zones in each $T_{\text {sed }}$ condition $\left(T_{\text {sed }}<0.5 \mathrm{~km}, 0.5 \mathrm{~km} \leq T_{\text {sed }}<\right.$ $1 \mathrm{~km}$ or $\left.T_{\text {sed }} \geq 1 \mathrm{~km}\right)$ and $M_{\max }$ class with the corresponding distribution among the synthetic dataset $\left(N_{\text {synth }}\right)$, whose frequency histograms are provided in the auxiliary material (Figure S3 in the auxiliary material). We perform the same comparison for each UPS condition $(\mathrm{E}, \mathrm{C}, \mathrm{N}$; frequency histograms in Figure $\mathrm{S} 4$ in the auxiliary material). In Figures $3 \mathrm{a}$ and $3 \mathrm{~b}$, we report the p-values of two null hypothesis tests: $\mathrm{H}_{0-1}: N_{\text {synth }} \geq N_{\text {real }}$ and $\mathrm{H}_{0-2}: N_{\text {synth }} \leq N_{\text {real }}$. The cases for which a significant $\mathrm{p}$-value is obtained are marked in red or blue if the test rejects respectively the $\mathrm{H}_{0-1}$ or the $\mathrm{H}_{0-2}$ null hypothesis (at the $5 \%$ significance level). In other words, the red/blue cells show the sets of $T_{\text {sed }}$ or UPS conditions (vertical axis) and $M_{\max }$ classes (horizontal axis) where the number of observed subduction zones is significantly higher/lower than expected by random chance. Both sets of simulations show that neither $T_{\text {sed }}$ (Figure 3a) nor UPS (Figure 3b) by themselves fully explain, with statistical significance below 5\%, both the abundance of GEQs in some types of subduction zones and their absence in others, as observed in Figure 2.

[15] The prediction of GEQ distribution is improved when considering $T_{\text {sed }}$ and UPS jointly, using the Fields 1, 2 and 3 defined in Figure 2 (Figure 3c; frequency histograms in Figure S5 in the auxiliary material). In particular, the latter set of simulations shows that the number of GEQs randomly-assigned to Field 3 is greater than or equal to the observed number (4 for $8.5 \leq M_{\max }<9.0$ and 4 for $M_{\max } \geq$ $9.0)$ less than $5 \%$ of the time. Similarly, the number of GEQs randomly-assigned to Field 1 is smaller than or equal to the observed number ( 0 for both $M_{\max }$ classes) less than $1 \%$ of the time. These statistics confirm that the preferential occurrence of GEQs in Field 3, and their absence in Field 1, is unlikely to arise by random chance. Repeating the analysis by random sampling of uniform distributions for $T_{\text {sed }}$ and UPS produces similar results. Specific details on the simulations performed and the results obtained can be found in the auxiliary material.

\section{Discussion}

[16] While our statistical analysis shows that GEQs occur most often at subduction zones that combine large $T_{\text {sed }}(\geq 1 \mathrm{~km})$ and neutral UPS, it is also apparent (Figure 2), that these two conditions are often associated with each other. In order to quantify possible dependence between $T_{\text {sed }}$ and $U P S$, we calculate their Spearman correlation coefficient. We find a low value $(\tau=0.41)$ associated with a very low p-value $(0.6 \%)$. As a result, the 
positive correlation between these parameters can be considered weak but not random. Thus, we cannot rule out a possible dependence between $T_{\text {sed }}$ and UPS. Indeed, it is noteworthy that $T_{\text {sed }} \geq 1 \mathrm{~km}$ is rarely associated with compressive UPS (Figure 2). The only two examples are the Colombia and Manila trench sections for which $T_{\text {sed }}$ remains $<1.5 \mathrm{~km}$, with large lateral variability that exhibits trench sediment thickness $<0.5 \mathrm{~km}$ observable over wide along-trench distances. All trench sections with trench sediment thickness $\geq 1.0 \mathrm{~km}$ continuous over large trench distances have neutral (or, in a few cases, extensional) UPS.

[17] It is difficult to conclude that thick trench sediments cause neutral UPS, or vice versa (or if both are controlled by other parameters), especially because such relationships have been poorly investigated by mathematical and physical models. However, there are possible explanations for causation in both directions. UPS should control the sediment supply at trenches through generation of relief and associated erosion (expected larger for compressive UPS) or by tuning the space available for channel sediments (assumed correlated to $T_{\text {sed }}$ ) to accumulate (expected larger for neutral or extensive UPS). Alternatively, a large thickness of sediments at seismogenic zone depths may not only promote lateral rupture continuation by smoothing the slipping interface [Ruff, 1989], but may also modify the transmission of tectonic stresses across the plate interface $[\mathrm{Lamb}$ and Davis, 2003]. Interplate stresses partly result from interplate pressure [Chemenda et al., 2000], which is thought to be caused by differential motion between the trench and the upper plate [Lallemand et al., 2008; Arcay et al., 2008]. The observed correlation may thus indicate that thick subduction channel sediments should promote neutral UPS by decreasing the intensity of interplate pressure, i.e., the efficiency of compressive stress transmission to the upper plate. This mechanism would thus set up a positive feedback that promotes GEQs for thick sediment environments. Although the relationship between the plate interface nature and UPS has been analyzed [De Franco et al., 2008; Kostoglodov, 1988], the associated influence of interplate pressure has not, and physical investigations are required.

\section{Conclusion}

[18] We explored the plate interface conditions for GEQ genesis by statistically analyzing, for worldwide subduction zones, the relations between $U P S, T_{\text {sed }}$, and $M_{\max }$. We found that the most favorable conditions for GEQ occurrence are $T_{\text {sed }} \geq 1 \mathrm{~km}$ combined with neutral UPS. Neutral UPS or $T_{\text {sed }} \geq 1 \mathrm{~km}$ separately give mean $M_{\max }$ values of 8.4 whereas the mean $M_{\max }$ value is 8.6 when these characteristics are combined together (Figure 2). Less frequent and lower magnitude (on average) GEQs are also possible for compressive UPS, at subduction zones with $0.5 \mathrm{~km} \leq$ $T_{\text {sed }}<1.0 \mathrm{~km}$ (e.g., Kamchatka, Colombia, S-Kuriles, N-Chile and Japan; Table S2 in the auxiliary material) and in areas that combine compressive UPS and $T_{\text {sed }}<1 \mathrm{~km}$ (N-Chile and Japan, although in these cases trench sediment thicknesses are locally greater than $1 \mathrm{~km}$ over several ten of kilometres along the trench; Table S2 in the auxiliary material). The only conditions for which GEQs have not been observed - and that might be inhibiting conditions are extensional UPS or $T_{\text {sed }}<0.5 \mathrm{~km}$. We thus verified that
GEQs are more likely where the $\left[T_{\text {sed }} ; U P S\right]$ conditions that promote trench-parallel earthquake rupture combine: 1- subduction of a continuous section of thick trench sediment $\left(T_{\text {sed }} \geq 1 \mathrm{~km}\right)$ that could construct, with elevated pressure at depth, a strong and laterally-homogenous layer that smoothes subducted sea-floor relief and strength-coupling asperities, and 2- moderate tectonic compressive stresses applied to the subduction interface (i.e., UPS neutral) that are high enough to allow frictional stresses to build-up, while low enough to avoid inhibition of rupture propagation along the plate interface.

[19] Acknowledgments. We thank Roland von Huene and Dave Scholl who helped to improve the quality of the original manuscript by their constructive suggestions. This research was supported as part of the Eurohorcs/ESF-European Young Investigators Awards Scheme (resp. F.F.), by funds from the National Research Council of Italy and other National Funding Agencies participating in the 3rd Memorandum of Understanding, as well as from the EC Sixth Framework Programme and NSF grant EAR-0914712 (C.P.C.).

[20] The Editor thanks Roland von Huene and David W. Scholl for their assistance in evaluating this paper.

\section{References}

Agudelo, W., A. Ribodetti, J.-Y. Collot, and S. Operto (2009), Joint inversion of multichannel seismic reflection and wide-angle seismic data: Improved imaging and refined velocity model of the crustal structure of the north Ecuador-south Colombia convergent margin, J. Geophys. Res., 114, B02306, doi:10.1029/2008JB005690.

Arcay, D., S. Lallemand, and M.-P. Doin (2008), Back-arc strain in subduction zones: Statistical observations vs numerical modelling, Geochem. Geophys. Geosyst., 9, Q05015, doi:10.1029/2007GC001875.

Bilek, S. L., S. Y. Schwartz, and H. R. DeShon (2003), Control of seafloor roughness on earthquake rupture behaviour, Geology, 31(5), 455-458, doi:10.1130/0091-7613(2003)031<0455:COSROE $>2.0$. CO;2.

Chemenda, A., S. Lallemand, and A. Bokun (2000), Strain partitioning and interplate friction in oblique subduction zones: Constraints provided by experimental modeling, J. Geophys. Res., 105(B3), 5567-5581, doi:10.1029/1999JB900332.

Clift, P., and P. Vannucchi (2004), Controls on tectonic accretion versus erosion in subduction zones: Implications for the origin and recycling of the continental crust, Rev. Geophys., 42, RG2001, doi:10.1029/ 2003RG000127.

Conrad, C. P., S. Bilek, and C. Lithgow-Bertelloni (2004), Great earthquakes and slab pull: Interaction between seismic coupling and plate-slab coupling, Earth Planet. Sci. Lett., 218, 109-122, doi:10.1016/S0012821X(03)00643-5.

Corbi, F., F. Funiciello, C. Faccenna, G. Ranalli, and A. Heuret (2011), Seismic variability of subduction thrust faults: Insights from laboratory models, J. Geophys. Res., 116, B06304, doi:10.1029/2010JB007993.

De Franco, R., R. Govers, and R. Wortel (2008), The nature of the plate contact and subduction zones diversity, Earth Planet. Sci. Lett., 271(1-4), 245-253, doi:10.1016/j.eps1.2008.04.019.

Heuret, A., and S. Lallemand (2005), Plate motions, slab dynamics and backarc deformation, Phys. Earth Planet. Inter., 149, 31-51, doi:10.1016/j. pepi.2004.08.022.

Heuret, A., S. Lallemand, F. Funiciello, C. Piromallo, and C. Faccenna (2011), Physical properties of subduction-type seismogenic zones revisited, Geochem. Geophys. Geosyst., 12, Q01004, doi:10.1029/ 2010GC003230.

Jarrard, R. D. (1986), Relations among subduction parameters, Rev. Geophys., 24, 217-284, doi:10.1029/RG024i002p00217.

Kodaira, S., N. Takahashi, A. Nakanishi, S. Miura, and Y. Kaneda (2000), Subducted seamount imaged in the rupture zone of the 1946 Nankaido earthquake, Science, 289, 104-106, doi:10.1126/science.289.5476.104.

Kostoglodov, V. (1988), Sediment subduction: A probable key for seismicity and tectonics at active plate boundaries, Geophys. J., 94, 65-72.

Lallemand, S. (1995), High rates of arc consumption by subduction processes: Some consequences, Geology, 23(6), 551-554, doi:10.1130/ 0091-7613(1995)023<0551:HROACB >2.3.CO;2.

Lallemand, S., P. Schnürle, and J. Malavieille (1994), Coulomb theory applied to accretionary and nonaccretionary wedges: Possible causes for tectonic erosion and/or frontal accretion, J. Geophys. Res., 99(B6), 12,033-12,055, doi:10.1029/94JB00124. 
Lallemand, S., A. Heuret, C. Faccenna, and F. Funiciello (2008), Subduction dynamics as revealed by trench migration, Tectonics, 27, TC3014, doi:10.1029/2007TC002212.

Lamb, S., and P. Davis (2003), Cenozoic climate change as a possible cause for the rise of the Andes, Nature, 425, 792-797, doi:10.1038/ nature 02049 .

Marzocchi, W., L. Sandri, A. Heuret, and F. Funiciello (2011), On the frequency-magnitude distribution of converging boundaries, Abstract S34A-06 presented at 2011 Fall Meeting, AGU, San Francisco, Calif., 5-9 Dec.

McCaffrey, R. (2008), Global frequency of magnitude 9 earthquakes, Geology, 36(3), 263-266, doi:10.1130/G24402A.1.

Meng, L., A. Inbal, and J.-P. Ampuero (2011), A window into the complexity of the dynamic rupture of the $2011 M_{w} 9$ Tohoku-Oki earthquake, Geophys. Res. Lett., 38, L00G07, doi:10.1029/2011GL048118.

Normile, D. (2011), Devastating earthquake defied expectations, Science, 331, 1375-1376, doi:10.1126/science.331.6023.1375.

Pacheco, J. F., L. R. Sykes, and C. H. Scholz (1993), Nature of seismic coupling along simple plate boundaries of the subduction type, J. Geophys. Res., 98, 14,133-14,159, doi:10.1029/93JB00349.

Ruff, L. J. (1989), Do trench sediments affect great earthquake occurrence in subduction zones?, Pure Appl. Geophys., 129, 263-282, doi:10.1007/BF00874629.

Ruff, L. J., and H. Kanamori (1980), Seismicity and the subduction process, Phys. Earth Planet. Inter., 23, 240-252, doi:10.1016/0031-9201(80) 90117-X.

Satake, K., and B. F. Atwater (2007), Long-term perspectives on giant earthquakes and tsunamis at subduction zones, Annu. Rev. Earth Planet. Sci., 35, 349-374, doi:10.1146/annurev.earth.35.031306.140302.

Schnürle, P., C.-S. Liu, S. Lallemand, and D. L. Reed (1998), Structural insights into the south Ryukyu margin: Effects of the subducting Gagua ridge, Tectonophysics, 288, 237-250, doi:10.1016/S0040-1951(97) 00298-9.
Scholl, D. W., S. H. Kirby, and R. von Huene (2011), Exploring a link between great and giant megathrust earthquakes and relative thickness of sediment and eroded debris in the subduction channel to roughness of subducted relief, Abstract TI4B-01 presented at 2011 Fall Meeting, AGU, San Francisco, Calif., 5-9 Dec.

Singh, S. C., et al. (2008), Seismic evidence for broken oceanic crust in 2004 Sumatra earthquake epicentral region, Nat. Geosci., 1, 777-781, doi:10.1038/ngeo336.

Uyeda, S., and H. Kanamori (1979), Back-arc opening and the mode of subduction, J. Geophys. Res., 84, 1049-1061, doi:10.1029/ JB084iB03p01049.

von Huene, R., and S. Lallemand (1990), Tectonic erosion along the Japan and Peru convergent margins, Geol. Soc. Am. Bull., 102, 704-720, doi:10.1130/0016-7606(1990)102<0704:TEATJA>2.3.CO;2.

von Huene, R., D. Klaeschen, B. Cropp, and J. Miller (1994), Tectonic structure across the accretionary and erosional parts of the Japan Trench margin, J. Geophys. Res., 99(B11), 22,349-22,361, doi:10.1029/ 94JB01198.

Wang, K., and S. Bilek (2011), Do subducting seamounts generate or stop large earthquakes?, Geology, 39, 819-822, doi:10.1130/G31856.1.

C. P. Conrad, Department of Geology and Geophysics, University of Hawaii at Manoa, 1680 East-West Rd., Honolulu, HI 96822, USA.

F. Funiciello and A. Heuret, Dipartimento Scienze Geologiche, Università "Roma TRE," Largo San Leonardo Murialdo 1, I-00146 Rome, Italy. (arnauld.heuret@gmail.com)

S. Lallemand, Géosciences Montpellier, CNRS, Université Montpellier 2, CC 60, Place E. Bataillon, F-34095 Montpellier CEDEX 5, France.

L. Sandri, Istituto Nazionale di Geofisica e Vulcanologia, Sezione di Bologna, Via D. Creti 12, I-40128 Bologna, Italy. 